\title{
Erratum
}

\section{Differentiation of human neuroblastoma cells toward the osteogenic lineage by mTOR inhibitor}

\author{
A Carpentieri, E Cozzoli, M Scimeca, E Bonanno, AM Sardanelli and A Gambacurta
}

Cell Death and Disease (2016) 7, e2202; doi:10.1038/cddis.2016.60; published online 21 April 2016

Correction to: Cell Death and Disease (2015) 6, e1974; doi:10.1038/cddis.2015.244; published online 12 November 2015

Since the publication of this paper, the publisher has noticed that the Open Access license is missing.
The corrected article appears online together with this erratum.

The publisher would like to apologize for any inconvenience caused. 